\title{
Home-based Manufacturing Work for Women in India
}

Drivers and Dimensions

\author{
Sona Mitra
}

Understanding home-based work in the context of contemporary capitalism based on an overdrive for global integration has been a core research theme for economists and other social scientists engaged with questions of the structure of labour and its impact on labour relations. Home-based work has also been explored extensively by researchers studying altered forms of labour relations vis-à-vis women workers, related to the question of emerging feminization of a certain type of work due to altered production processes, fuelled by a rapid rise in globalization. There are several dimensions to home-based work. While it is a statistical fact that a large part of such work has witnessed an increase under outsourced, subcontracted and informalized structures that are a part of global supply chains, and thus engages a large proportion of women workers, evidence also suggests that the existence of home-based work among women is not new to capitalism. Such forms of work existed even in pre-capitalist societies, albeit in differing forms of organization of production-not to ignore the fact that the oldest forms of organization of work rested on workers at home. Thus the current system of capitalist production via global integration reorganizing itself into home-based processes of production can be seen as a continuation of the process of reorganization of production according to the needs of accumulation of capital, marked by various elements of change.

This paper challenges the existing claims of the emergence of home-based manufacturing work among women in India. It highlights that a large part of home-based women's work in India has been driven by local factors that have driven the overall demand for manufacturing employment among women. It argues that women's manufacturing work in India has had a large component of home-based organization of work that was utilized by the global value chains, and not the other way around. The paper attempts to substantiate that the existence of home work pre-dates the process of global integration, and questions the claims that newer forms of homebased work for women were generated by such integration.

(C) SONA MITRA, 2022 | DOI:10.1163/9789004499614_022

This is an open access chapter distributed under the terms of the CC BY-NC-ND 4.o license. 
In addition, the paper cites extensive data from secondary sources that capture the essence of women's home-based work. All such work is categorized under self-employment, which is clearly problematic given the current organization of production processes for home-based work. The paper is structured to include a brief review of the existing forms of home-based manufacturing/ industrial work among women, and provides an overview of the magnitude and dimensions of the existing forms. Examining secondary evidence provided by the Government of India's Employment-Unemployment Surveys, the paper explains how the data have been interpreted, and the issues associated with enumerating and recording home-based work of women in India. Two sections focus on manufacturing sector output and employment patterns, and how this affected women's manufacturing work. The final section of the paper underlines the overall manufacturing growth trajectory and the important role played by women's home-based work, to establish the argument that global value chains were not the most important drivers of women's home-based manufacturing work in India. The paper concludes by discussing important questions around women's home-based work in India's manufacturing sector as enumerated in existing data systems, towards a potentially better understanding of such work for women.

\section{A Longer View on the Existence of Home-based Work: A Brief Review}

The literature on a longer view of home-based workers has provided enough evidence of the existence of home-based work even in pre-capitalist societies, the putting-out form of production being an example. However, even after the industrial revolution and the evolution of factory-based forms of production in the mid-nineteenth century, home-based work was not obliterated completely. Scholars have provided evidence to show that a form of home-based work evolved that was connected with industry, commonly referred to as "industrial home work".

While the early phase of capitalism required the factory-based systems of production to be established as the most important form of surplus appropriation, the advance of capitalism, especially in the twentieth century and thereafter, essentialized the necessities of expanding the process of production to

1 Eileen Boris and Elisabeth Prügl (eds), Homeworkers in global perspective: Invisible no more (New York and London, 1996); Elisabeth Prügl, The global construction of gender: Home-based work in the political economy of 2oth century (London, 1999). 
countries with ready availability of a reserve labour force, accessible at much lower rates. This albeit was accompanied by massive alteration in the organization of production, which led to the development of global value chains and supply networks. Such changes in the forms of production were absolutely compatible with the requirements of rapid global integration of the already transformed capitalist economies of the global North with the less developed and transition economies of the global South, as they not only provided access to large markets for the global corporations in those regions, but also simultaneously provided access to cheap and flexible labour reserves, especially that of women, to expand the process of surplus accumulation. Thus, the current form of globalization has not only ushered in a process of capital accumulation based on the re-emergence of free markets, removal of tariff barriers and ushering in of free trade agreements, it has also led to an overwhelming increase of women workers in the manufacturing sector across all Asian countries as the organization of production kept altering its forms. The process of restructuring of global labour markets and the emergence of the new industrial division of labour were a consequence of such altered production processes.

However, this kind of "feminization" of employment in labour-intensive manufacturing in Asia's export processing zones or special economic zones (with women accounting for between 70 to 90 per cent of the workforce) peaked and eventually went into decline post the economic crisis in the developing South, especially in the developing Americas, in the early and mid-199os, and the Southeast Asian crisis of 1997-98. ${ }^{2}$ It also led to increased defeminization of factory-based women's work in manufacturing, and also informalization of overall labour markets, especially that of women's work. ${ }^{3}$

Such a process was a testimony to the arguments provided by feminist scholars regarding the use of "women as reserve army". It has been historically argued with substantial supporting evidence that the usefulness of women workers lay in the fact that not only could they be drawn in and thrown out of wage labour at different points of the development of capitalism, but they were perceived to be "more tractable and subservient to managerial authority, less prone to organize into unions, more willing to accept lower wages because

2 William Milberg and M. Amengual, Economic development and working conditions in export processing zones: A survey of trends (Geneva, 2008); Ingeborg Wick, Women Working in the Shadows: The Informal Economy and Export Processing Zones (Munich, 2010); Sheba Tejani and William Milberg, "Global Defeminization? Industrial Upgrading and Manufacturing Employment in Developing Countries", Feminist Economics, 22:2 (2016), pp. 24-54.

3 Tejani and Milberg, "Global Defeminization"; Jayati Ghosh, Never Done and Poorly Paid: Women's Work in Globalizing India, Feminist Fineprint (Delhi, 20o9). 
of their own lower reservation and aspiration wages, and easier to dismiss using life-cycle criteria such as marriage and childbirth".

In the newer forms of accumulation, especially in the late twentieth century and the twenty-first century, where the production process is marked by fragmented, subcontracted, outsourced mechanisms and complex networks of global value chains, especially in the production of specific export commodities, the inherent tractability, adaptability and flexibility associated with women workers also facilitated such processes by transforming the households themselves into sites of production for exchange-values in addition to being sites for consumption, as per the needs of contemporary capitalism. ${ }^{5}$ The literature on the existence of such work organizations thus makes a connection between home-based work and current patterns of production processes. It presents this kind of home-based worker as an integral part of the supply chains under current forms of globalized production, which in turn have been replicated by the domestic/more localized value chains in developing countries. Therefore, while such trends of increased home-based work may substantially be linked to greater economic integration and have constituted a large part of the evidence on globalization and its impact on women's work in developing and low-income countries, it is also required that the discourse on home-based work is integrated with the larger context of women's manufacturing work.

Dimensions and Organization of Home-based Work in Developing Regions

The ILO report on Women and Men in the Informal economy (2013) provided macro evidence of a concentration of women in home-based work in most developing regions of the world. It showed that among home-based workers, 62 per cent in South Africa, 70 per cent in Brazil and 88 per cent in Ghana were women. The majority of home-based workers remained informally employed, as in the case of 60 per cent in Buenos Aires and 75 per cent in South Africa. The report clearly mentioned that a significant proportion of home-based workers was to be found in manufacturing and trade. In South Africa, 24 per

4 Unescap, Sustainable Social Development in a Period of Rapid Globalization: Challenges, Opportunities and Policy Options (Bangkok, 2002).

5 Guy Standing, "Global Feminization through Flexible Labor: A Theme Revisited", World Development, 27:3 (1999), pp. 583-6o2; Milberg and Amengual, Economic development and working conditions in export processing zones. 
cent of all home-based workers were involved in manufacturing. The report also cited evidence of subcontracted home-based work among brick-makers, stone masons, construction workers and hand-packers. Further, in Buenos Aires, 33 per cent of all home-based workers were in manufacturing and 42 per cent of women home-based workers were in manufacturing. Home-based work for women also accounted for self-employment in women workers and this formed a bulk of women's work in South Asia. ${ }^{6}$

The ILO report suggested that there were at least 41 million home-based workers outside agriculture in South Asia alone, representing 15 per cent of total non-agricultural employment (and 31 per cent of female non-agricultural employment) in India, and as much as 40 per cent of total non-agricultural employment (and 48 per cent of female non-agricultural employment) in Nepal. In India, the number of home-based workers was 37.4 million in 2011-12, the last available figure from a large and detailed sample survey conducted to estimate the situation of employment and unemployment in India at the time of writing. The data also suggest that subcontracted workers represent between 14 per cent (Bangladesh) to 33 per cent (India and Pakistan) of all home-based workers; and as high as 45 per cent (India) to 6o per cent (Pakistan) of women home-based workers. ${ }^{7}$ In India, home-based manufacturing work for women accounted for almost 70 per cent of total female manufacturing work in 2011-12. More than one million women in the manufacturing sector in India were home-based workers. Apart from the current organization of home-based work noted above, much of this work came in the form of a wide range of activities.

Many of the female activities within manufacturing, were commonly the more traditionally "feminized" ones (being "light" as they did not use heavy equipment or machinery, but no less arduous in terms of the long hours of work and the nature of repetitive, mechanical tasks involved) and thus underlined the importance of such work for women in manufacturing. These activities were also well-adjusted within the arrangements of organization of work under home-based production systems. Under these arrangements,

workers produce goods and services for both global and domestic supply chains from within and around their homes. By the several accounts provided by WIEGO, the most common sub-contracting arrangements involve home workers providing the workplace, pay for utilities, buy/rent

6 International Labour Organization (ILO), Women and Men in the Informal Economy: A Statistical Picture, second edition (Geneva, 2013).

7 Ibid. 
and maintain their own equipment. The contractors provide the work orders and raw materials, specify the products to be made, and supply firms further up the chain with the finished goods. In a few cases, the home worker may herself be a sub-contractor who splits the order and raw materials that she receives among other women in her "group" in which they work together. ${ }^{8}$

Whatever the arrangements, the access to the market for home workers remains limited due to their limited exposure within supply chains. In addition, following the perception of home-based work being subordinate to factory work as well as women's subordinate status in the labour market, in most of these arrangements, women are paid piece-rates—which are much lower on average than what factory workers in the same supply chains are paid-without any non-wage benefits. The payments also do not refurbish any depreciation costs on equipment or reimburse transport costs associated with delivery of finished goods or acquiring raw materials incurred by the home-based workers.

Thus, towards the end of the twentieth century and thereafter, home-based work emerged mostly as a part of global production networks, either as subcontracted or outsourced work by large multinational corporations (MNCs). The alteration in the organization of production from singular to fragmented processes, not only divided by stages of production but also located across different regions in different countries and also in different locations within the countries, witnessed a surge of such work being performed within households, mainly using the principles of comparative advantage in the cost of labour realized under such organization of work. ${ }^{9}$ And within such a process, women workers working out of their homes were at the bottom of such labourintensive global supply chains, particularly in those that are relatively more globally integrated in terms of production. They received the worst remuneration, and worked under poor conditions. ${ }^{10}$

In most of the emerging and transition economies that were adapting export-oriented strategies for the growth of output in the manufacturing sector in the latter part of the twentieth century, the bulk of the women were

8 Govindan Raveendran, Ratna M. Sudarshan and Joann Vanek, "Home-Based Workers in India: Statistics and Trends", WIEGO Statistical Brief No. 10 (2013), pp. 1-9.

9 Jeemol Unni and Suma Scaria, "Government Structure and Labour Market Outcomes in Garment Embellishment Chains”, Working Papers id: 3061, eSocialSciences (2010).

10 Marilyn Carr, Martha Alter Chen and Jane Tate, "Globalization and Homebased Workers", Feminist Economics, 6:3 (2000); Renana Jhabvala, "Informal Workers and the Economy", Indian Journal of Industrial Relations, 48:3 (2013). 
located within informal employment, often employed as casual and temporary workers who served as a "buffer workforce" for product chains, both global and local. The objectives of such employment were mostly to accommodate just-in-time ordering, fluctuations in orders and prices, and stiff competition among suppliers. This in turn influenced the nature of activities that women performed within the sector, which, coupled with the social constructs around women's physical abilities, often ascribed "light work" to them in manufacturing. These were the precise factors for a relatively greater concentration of women workers in specific manufacturing sectors, such as textiles, garments, leather and footwear, and electronics, and even within specific buyer-driven food-processing industries, which also happen to be the export-oriented production sectors. Much of such work also happens to involve "light equipment and tools" and the use of simple technology that does not always require elaborate factory set-ups. Finally, the predispositions vis-à-vis the preferences of women workers to work from home in order to be able to both participate in paid activities as well as manage unpaid and care commitments do have a role to play even in specific manufacturing employment, which can be performed from home. Such preconceived notions attached to women's abilities have encouraged the participation of a large number of women in such homebased work. Further, these notions have played a role in evolving the current organization of home-based manufacturing work, which has become an effective tool for the process of capital accumulation that exploits the cheapest and most easily accessible form of labour.

While the above formulation of globalization-driven home-based work, especially for women, holds true for most countries that embarked upon the path of globalized export-oriented growth strategies, for example, countries in East and Southeast Asia, Bangladesh, Sri Lanka in South Asia, and some others such as Turkey, Mexico, Brazil and Peru, the case of India stands apart. In India, globalization and economic integration followed a different path, which did not necessarily involve globalization of the manufacturing sector, i.e. there was no export thrust to the manufacturing sector as in other countries. As a result, home-based work, even as it existed in large measure for women in manufacturing, was not driven by the above factors. The drivers of home-based work in India were different in character as compared to the experiences of other developing countries. Such differences emerged primarily due to the unique features of India's high growth trajectory in general amidst stagnation of the manufacturing sector in particular. The repercussions of such stagnationboth in terms of the volume of work and the conditions of work - were felt in all forms of women's home-based work. 
The above argument is backed by secondary sources of information on women's home-based work in India. This paper uses the Employment and Unemployment estimates provided by the National Sample Survey Organization (NSSO) of the Government of India in its major rounds since 1993-94, which cover the period of neoliberal economic reforms in India. The study is restricted to employment estimates up to 2011-12, as those are the latest available figures from a comparable data source. ${ }^{11}$ Output growth figures are used from the National Accounts Statistics provided by the Central Statistical Organization (CsO), Government of India.

\section{The Indian Growth Story: Setting the Context}

The Indian growth story has often been cited as one of the success stories of globalization. However, the trajectory of the Indian growth process has been unique among the experiences of developing countries. India has sustained a relatively high rate of growth over several decades, which saw acceleration since 2002 and marginal lowering since 2009 for some years.

The proponents of globalization attributed the transition to this higher growth path to the economic reforms of 1991. An analysis of the growth strategies reveals clear shifts in the policies pursued: from a regime of increased fiscal stimulus provided by public expenditure in the 1980 os to one of marketdriven growth since the 199os. Broadly, the macroeconomic strategy pursued to achieve high rates of growth in the 199os and after was largely dependent upon (i) greater reliance on exports, especially of services, and (ii) increased

11 The data on home-based work in India's labour force statistics (LFS) are bound by a caveat. While the ILO defines two specific categories within home-based work, the LFS in India do not provide such distinctions. The two categories of home-based work are: (i) independent self-employed workers who take entrepreneurial risks; and (ii) other homebased workers dependent on a firm or its contractors for work orders, supply of raw materials and sale of finished goods. This second category of home-based workers is referred to as subcontracted workers/home workers. Since they are not directly supervised by an employer and provide their own workspace and equipment, they are routinely classified as self-employed by the LFS in India. The ILO's basis of distinction stems from the conceptual differences in categorizing home-based work into self-employed and wage-employed categories, as the latter, being dependent on a firm or its contractor for work orders, raw materials and sale of finished goods, should be conceptually classified as wage work. The Indian data system does not allow for such a distinction and hence the bulk of homebased workers in India are classified in the category of self-employed. This may limit the analysis to a small extent but the larger arguments get substantiated in the following discussion. 
dependence on capital inflows, primarily of the short-term variety. The policies not only included removal of several tariff restrictions for facilitating international trade in goods and services, but also easing of rules for cross-border capital flows with the aim of attracting foreign investment. Thus, apart from trade liberalization, some of the other policies included a series of concessions to reform the structure of tax policies, and deregulation of financial markets including partial removal of restrictions on capital mobility. The latter policy was meant to attract foreign investment and make India one of the world's most favoured destinations for international capital so as to boost investment ratios. Such theorization became more dominant in the 20oos. While it is a statistical fact that post-2002-O3 the GDP growth of India rose rapidly, whether this was a consequence of increased investment or due to the concessions provided to the financial markets has been widely debated.

An important feature of the Indian growth story was the slowing down of the manufacturing sector, despite the open market strategies, the tax concessions, and the trade liberalization policies followed aggressively by the Indian state. Studies on India's earnings from exports and on the nature of foreign capital entering India clearly reveal two important factors. First, the high rates of growth in India were not driven by foreign direct investments (FDI), as shown in a comprehensive study indicating that despite concessions, India failed to attract the desired quantum of foreign investments in the manufacturing sector. $^{12}$ This finding gets further corroborated by the second factor. An analysis of capital inflows clearly indicate that the above-mentioned concessions which facilitated large increases in the flow of capital into India were mainly in the form of external commercial borrowings, portfolio investments and short-term credit, rather than due to India's prowess in merchandise export earnings. ${ }^{13}$

Another important factor responsible for driving growth over the period was internal financial liberalization and banking reforms, which resulted in a process of institutional change in which the role played by state-owned financial institutions and banks was substantially altered. These changes led the banks to adopt a newer strategy of credit allocation, which further led to huge increases in the bank credit to GDP ratio from 2005 onwards. These changes were not driven by increased credit to the productive sectors of the economy.

12 K S Chalapati Rao and Biswajit Dhar (2014). FDI into India's Manufacturing Sector via M\&As: Trends and Composition, Working Paper \#161, Institute for Studies in Industrial Development, New Delhi.

13 C.P. Chandrasekhar, 2008. Financial Liberalization and the New Dynamics of Growth in India, Third World Network, Global Economy Series \#13; also available at www.twn.my, last accessed 2 June 2021. 
Instead, retail loans became the prime drivers of credit growth. The result was a sharp increase in the retail exposure of the banking system, with overall personal loans increasing from slightly more than 8 per cent of total non-food credit in 2004 to close to 25 per cent by 2008 . This of course resulted in a boom in retail credit consumption by the upper deciles of the population, especially in the urban areas. Of the components of retail credit, the growth in housing loans was the highest in most years. ${ }^{14}$

Thus, the surge in growth could be attributed to greater global integration associated with increased speculative activities around the financial, housing and real estate sectors. This resulted in fuelling private consumption of the elite and burgeoning middle classes, which emerged as the main driver of the high rates of growth. It needs to be highlighted that the earlier emphasis on public spending as the principal stimulus for growth was gradually substituted with speculative financialization, which unfortunately had a range of repercussions for the sectoral performance of the Indian economy. The Indian economy over the period has been marked by uneven sectoral performance, with all other sectors except services facing low growth or stagnation. Manufacturing especially had had a volatile performance since the 199os, despite aggressive neoliberal policies.

\section{Manufacturing Output and Employment Growth in the Period of Globalization}

A closer look at the sectoral composition of growth confirms the fact that the high rate of GDP growth was not contributed by the manufacturing sector, much to the dismay of the proponents of neoliberal policies. The manufacturing sector growth rate in the 199os averaged $5^{-6}$ per cent per annum and increased to 9 per cent during the high growth period, declining thereafter post-2010 (Graph 19.1). While the growth rate of the sector showed fluctuations, the sectoral contribution of manufacturing to GDP stagnated at around 16 per cent, implying reduced importance of the sector in the overall growth story of India (Graph 19.2). Thus, an important feature of the Indian trajectory of growth has been not a transition from agriculture to industry but a direct transition from agriculture to services, in terms of shifts in the sectoral contribution to GDP. Such transitions have had direct implications for non-agricultural

\footnotetext{
14 C.P. Chandrasekhar and Jayati Ghosh, "Growth, Employment Patterns and Inequality in Asia: A Case Study of India”, ILO Asia-Pacific Working Paper Series (Bangkok, 2014).
} 


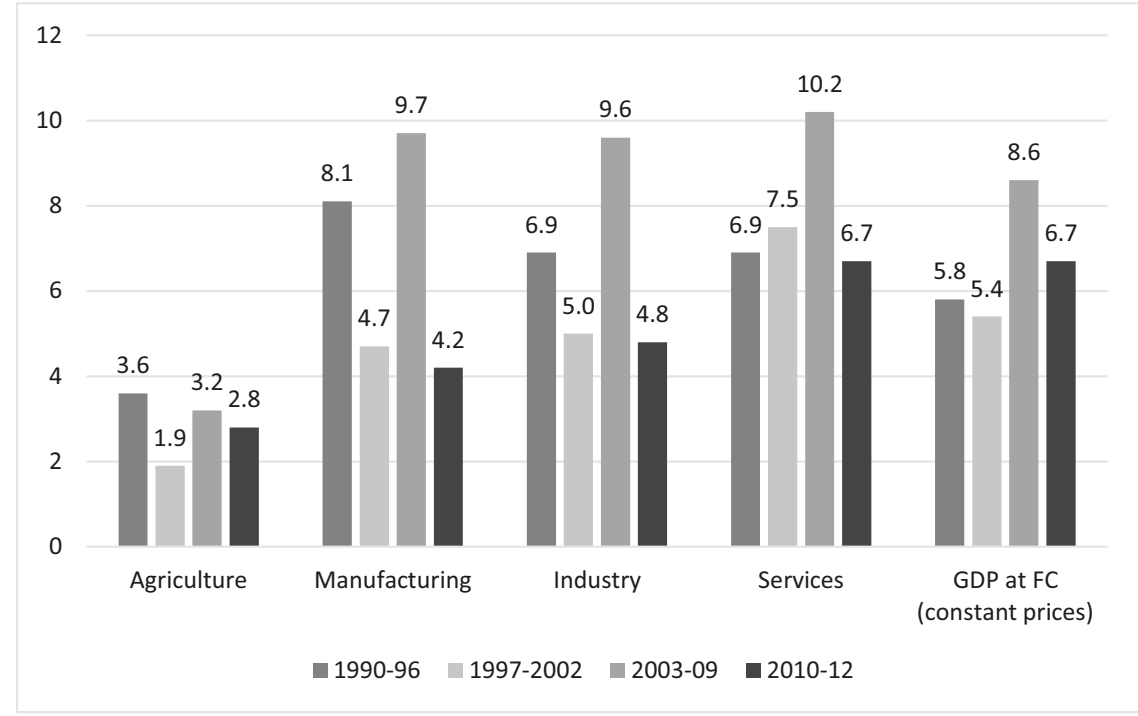

GRAPH 19.1 Average annual rate of growth of output by sectors, 1990-2012 (\%) SOURCE: COMPILED FROM NATIONAL ACCOUNTS STATISTICS, CSO, GOVERNMENT OF INDIA

120

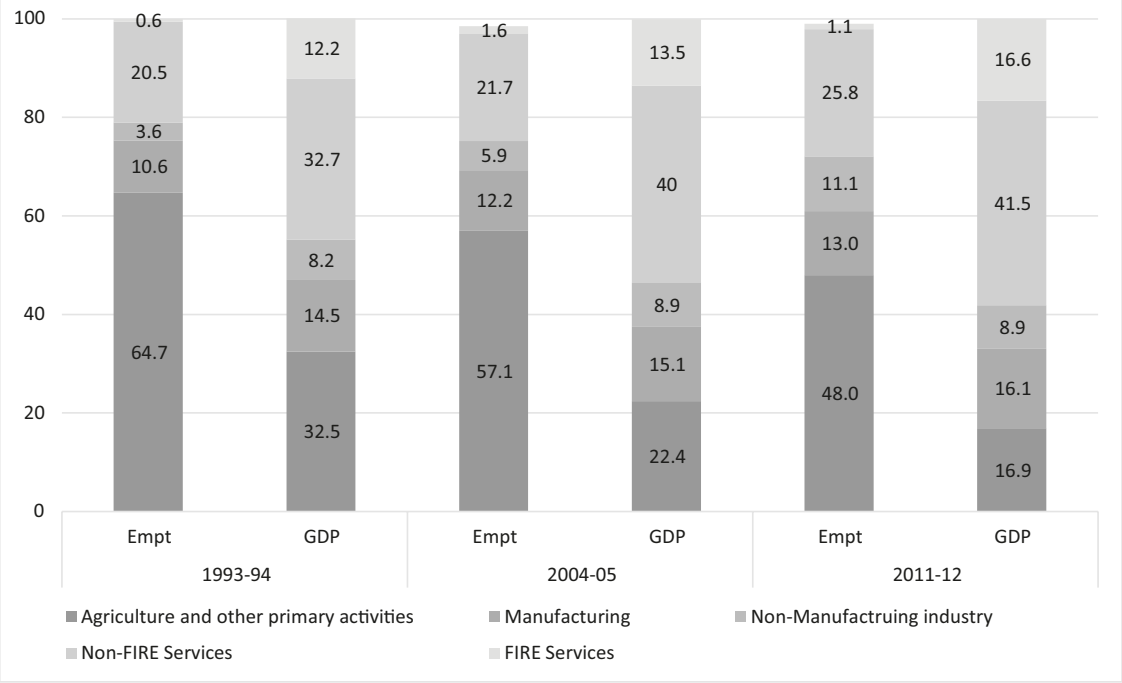

GRAPH 19.2 Sectoral contributions to employment and GDP, 1993 to 2012 (\%)

SOURCE: COMPILED FROM NATIONAL ACCOUNTS STATISTICS, CSO AND EUS, NSSO, GOVERNMENT OF INDIA, VARIOUS YEARS 


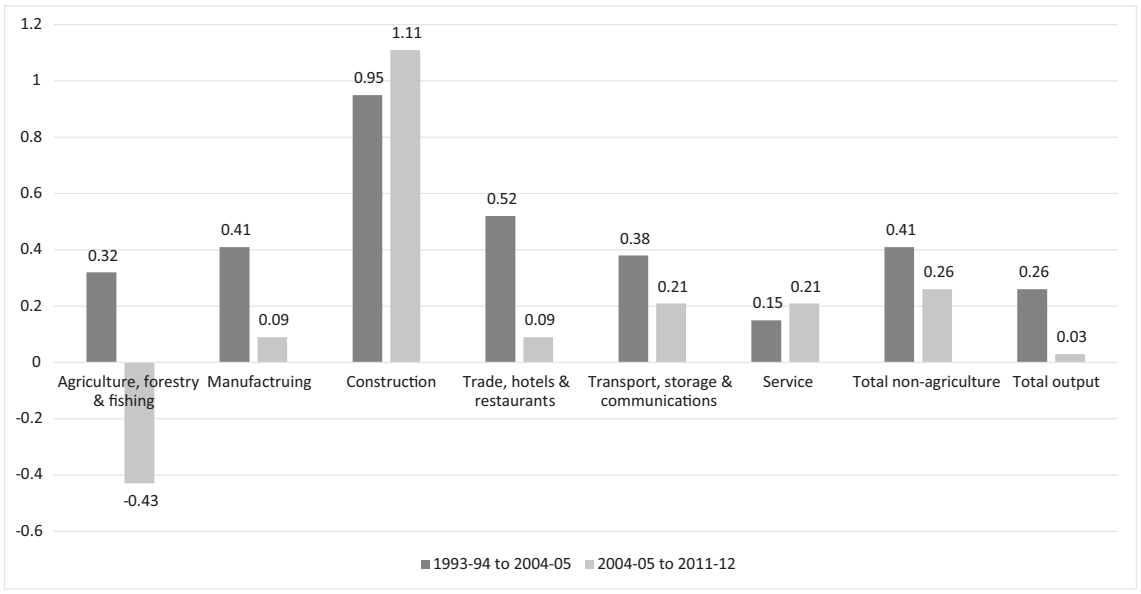

GRAPH 19.3 Output elasticity of employment by sector, 1993-94 to 2011-12 SOURCE: CALCULATED FROM ESTIMATES PROVIDED BY NAS AND EUS OF NSSO, GOVERNMENT OF INDIA, VARIOUS YEARS

employment in general and manufacturing employment in particular. The share of manufacturing employment to total employment showed stagnation at 12-13 per cent over the period, indicating a lack of labour-absorptive capacity of the sector over the period.

The overall output elasticity of employment at 0.03 shows that over the high growth period, there was an employment generation problem. Within that, substantially low elasticity in the traditionally labour-intensive manufacturing, one of the largest declines in the high growth period among the nonagricultural sectors, confirmed the reduced capacity of the sector to create additional employment with increases in output (Graph 19.3).

The trend of a slowdown in manufacturing employment was clearly a result of the policies followed by the government, which somewhat neglected the productive capacities of labour-intensive sectors such as manufacturing and so the overall growth was unable to create employment commensurate with the rate of growth of GDP. The unevenness of sectoral growth patterns also indicate that while the drivers of economic growth remained confined to the financial sectors, employment generation suffered in the traditionally labourintensive sectors, especially manufacturing.

\section{$5 \quad$ Women Workers in the Manufacturing Sector}

The above process directly impacted the lives of women workers, especially those in the non-agricultural sectors, as the manufacturing sector played a 


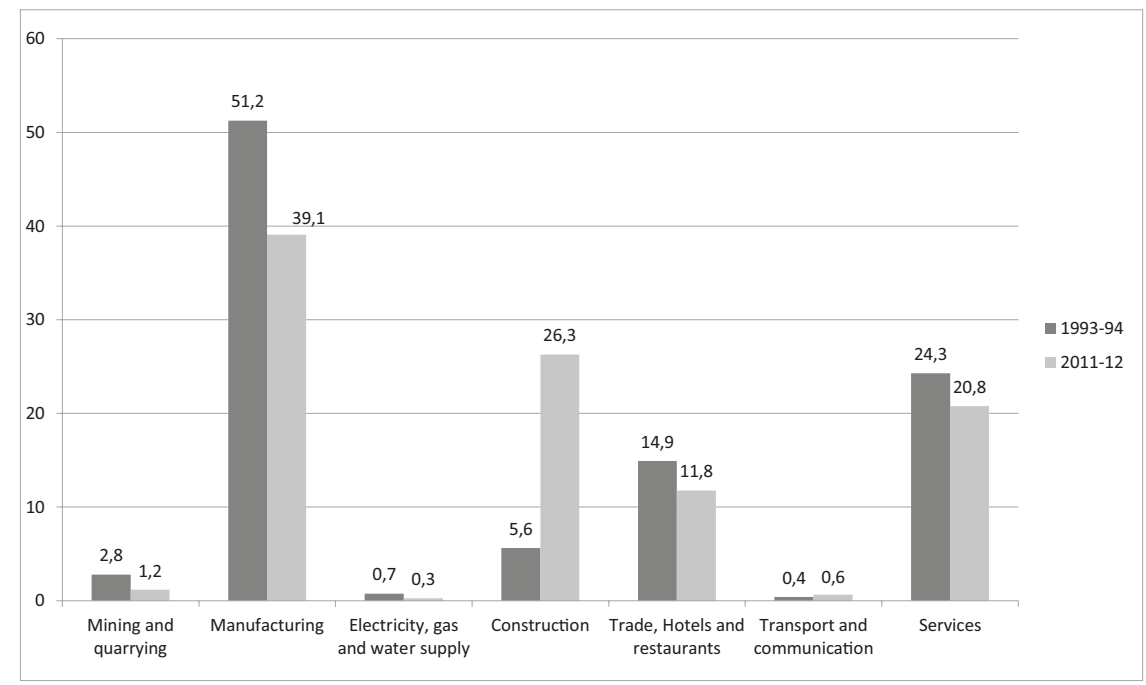

GRAPH 19.4 Distribution of usual status rural non-farm women workers SOURCE: CALCULATED FROM UNIT-LEVEL ESTIMATES OF EUS, DATA CDS FROM NSSO, VARIOUS YEARS

significant role as an employer of a large section of non-agricultural women workers, both in rural and urban areas. Graphs 19.4 and 19.5 show the distribution of women workers in non-agricultural sectors by broad industrial classification, and the changes over the period for rural and urban women workers. While the figures show large-scale concentration of non-agricultural women workers within manufacturing, they also reveal the sector's declining importance in more recent years, especially in urban areas. In rural areas, manufacturing continued to be the largest employer of women engaged in non-agriculture. In this section, we look at rural and urban women's manufacturing work separately in order to understand the importance of such work among women.

\section{$6 \quad$ Rural}

In the rural areas, women workers employed in manufacturing constituted around 9.2 million out of the total of 94 million rural women workers. Despite the fact that the sector accounted for almost 40 per cent of all non-agricultural women workers in rural areas, the rate of growth of manufacturing employment for women in rural areas was only 2.1 per cent over the long period of 1993-94 to 2011-12, one of the lowest employment growth rates registered for women workers in the non-agricultural sectors. In absolute terms, there was 


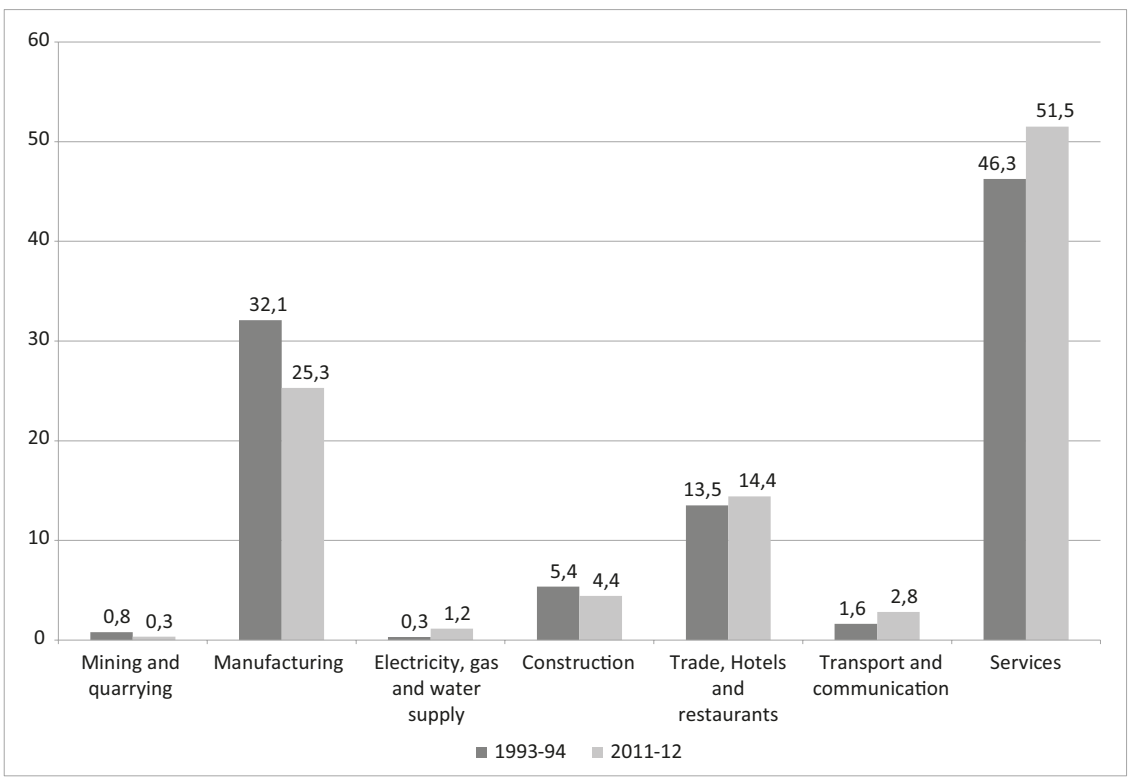

GRAPH 19.5 Distribution of usual status urban non-farm women workers SOURCE: CALCULATED FROM UNIT-LEVEL ESTIMATES OF EUS, DATA CD S FROM NSSO, VARIOUS YEARS

an addition of 2.6 million women workers to the manufacturing sector over this period.

The distribution of rural women workers within the manufacturing sector reveals an overwhelming presence of bidi workers, at 36 per cent. This was followed by garments and related activities, food processing, wood, cane, rattan, reed, bamboo products, spinning, weaving and finishing of textiles, and the manufacture of refractory and structural clay products, in that order (Graph 19.6). It is evident that employment was confined mostly to the traditional sectors. Among these, traditional manufacturing activities such as food processing, spinning and weaving of textiles, pottery and related activities showed declines in their shares. Spinning and weaving activities especially showed a phenomenal decline in employment. One possible explanation for this decline is the replacement of handloom by powerloom production, which displaced a large section of women workers. Several studies have shown such trends.

Disaggregating manufacturing sector employment to the lowest digit of industrial classification and comparing them across the years shows that major increases in manufacturing employment for rural women took place in: processing and preservation of marine products, manufacturing of bakery and farinaceous products, and processing of edible nuts within food processing; 


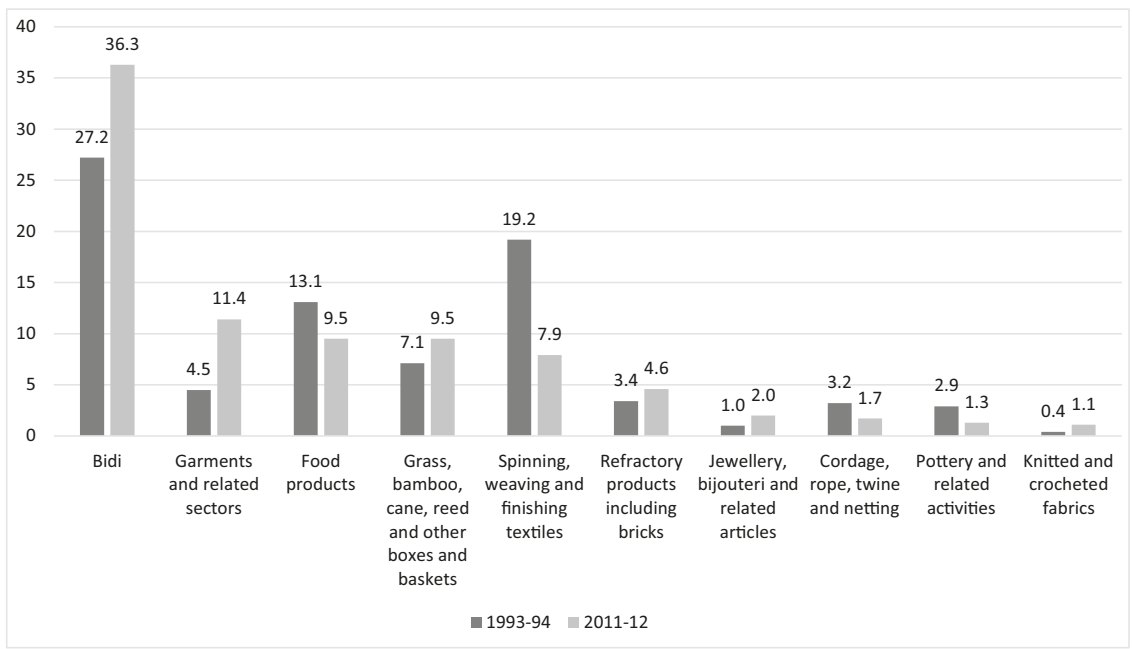

GRAPH 19.6 Distribution of rural women workers in manufacturing employment, 1993-94 and 2011-12

SOURCE: CALCULATED FROM UNIT-LEVEL EUS DATA FOR 1993-94 AND 201112, NSSO, GOVERNMENT OF INDIA

embroidery work, zari work, and making of laces, fringes and ornamental trimmings within garments; manufacture of knitted and crocheted fabrics; manufacture of artificial jewellery; and manufacture of soap, detergents, incense sticks, wood and cane products, refractory and clay products (mainly bricks) among others (Table 19.1). Table 19.1 reveals the absolute decline in traditional manufacturing, namely spinning, weaving and finishing of textiles, pottery and related activities, and manufacture of rope, netting, etc. Among these, spinning, weaving and finishing of textiles was a major employer of both men and women in 1993-94, which saw considerable depletion by 2011-12. The table also suggests that although bidi was the largest employer of women workers in rural manufacturing, it increased by a little more than $5^{6}$ per cent, which was much lower compared to some others, namely garments and related sectors. With a 198 per cent increase in rural women's employment in garments and related sectors, it was the second most important group of manufacturing activities after bidi.

These figures suggest a slowdown in women's engagement in traditional activities without much increase in newer manufacturing activities. However, manufacturing of refractory products, which includes manufacturing of bricks, emerged as a large employer of women in rural and urban areas. In the rural areas, it constituted 3.4 per cent of total women's manufacturing work and featured as one of the top five activities in the manufacturing sector in 2011-12. 
TABLE 19.1 Change in employment in select rural manufacturing sectors, 1993-94 to 2011-12

Sector details

Major manufacture of food products of which:

Processing and preserving of fruit and vegetables (includes jams, pickles, etc.)

Processing and preserving of fish, crustaceans and molluscs and products Grain-milling and other related products Manufacture of bakery products (includes manufacture of farinaceous products like pasta, macaroni, noodles, etc.)

Manufacture of cocoa, chocolate and sugar confectionery

Processing of edible nuts

Manufacture of food products n.e.c.

(includes grinding and processing of spices, manufacture of papads, appalams and similar food products)

Spinning, weaving and finishing of textiles of which:

Preparation and spinning, weaving, manufacture and finishing of cotton and blended cotton textiles Preparation and spinning, weaving, manufacture and finishing of other textiles (includes silks, wool, blended)

Major garments and related sectors of which:

Embroidery work, zari work and making of laces, fringes and ornamental trimmings Manufacture of all types of textile garments and clothing accessories

Manufacture of made-up textile articles, except apparel

Other manufacturing

$\begin{array}{ll}\text { Rural female } & \text { Rural female } \\ \text { absolute } & \% \text { change } \\ \text { difference } & \end{array}$
2029

$-124288$

3284

54754

9794

23298

100286

128.8

$-169497$

$-72.6$

$-649853$

$-406696$

$-243156$

586747

$197 \cdot 5$

576523

2918

7306

$17 \cdot 7$

1418697 
TABLE 19.1 Change in employment in select rural manufacturing sectors (cont.)

\section{Sector details}

\section{Rural female Rural female absolute \% change difference}

\section{of which:}

Bidi

Knitted and crocheted fabrics

Cordage, rope, twine and netting

Wooden and cane boxes, crates, drums,

barrels, baskets and other wares made

entirely or mainly of cane, rattan, reed,

bamboo, willow, fibres, leaves and grass

Soap and detergents, cleaning and

27395

96.2

polishing preparations, perfumes and toilet

1014738

58646

253.3

$-79995$

263745

56.1

preparations and agarbatti (incense sticks)

Refractory products and structural clay products

Articles of porcelain or china, earthenware, imitation porcelain or common pottery, including earthen statues Cutting, shaping and finishing of stone Jewellery, bijouterie and related articles A. Total select manufacturing

B. Total manufacturing employment

C. Total non-primary employment

$\begin{array}{rr}9500 & 14.5 \\ 88062 & 135.7 \\ 1217415 & 22.1 \\ 1157363 & 17.6 \\ 10871856 & 87.5\end{array}$

SOURCE: UNIT-LEVEL EUS DATA FOR 1993-94 AND 2011-12, NSSO, GOVERNMENT OF INDIA.

Apart from the above, some interesting findings emerge from Table 19.1 regarding food processing work for women. The decline in overall food processing in absolute terms - led by grain- and flour-milling activities, manufacture of papads and appalams, and grinding of spices-clearly occurred due to a change in the production process, which became more mechanized and less labour-intensive, thus moving into factory-based production and leading to a decline in women's participation in these activities. The activities within food processing that showed increased participation were the processing of marine products and edible nuts, which used traditional methods and constituted 
much of the home-based work. In addition, the concentration of women in bidi, embroidery and zari work, lace-making and so on show the predominance of manufacturing work among women that is home-based rather than factory-based.

The trends thus confirm that women workers in manufacturing, though diminishing in an overall sense, remained trapped within less productive manufacturing activities, where women were mostly concentrated in homebased set-ups rather than factory-based processes. While some of the traditional home-based production processes such as milling and spinning/weaving shifted to factory-based mechanized processes, others such as bidi, rolling of incense sticks, processing edible nuts and so on continued to prevail within home-based set-ups. In addition, some other activities emerged within homebased work, such as the processing of marine products, embroidery and other garment-related manufacturing activities.

In the urban areas, the rate of growth of women's employment over the period 1993-94 to 2011-12 was a mere 2.4 per cent, one of the lowest rates of growth of employment when compared to all other non-agricultural sectors. It also implies an addition of a mere 1.5 million women workers to the sector over a period of almost two decades, although the sector employed a substantial section of urban women workers (almost 5 million, or a quarter of all nonagricultural women workers) and was the second largest employer of women workers in urban areas.

The distribution of urban women workers within manufacturing employment showed that a few traditional manufacturing occupations, such as food processing, bidi manufacture, preparing wooden and cane articles, spinning, weaving and finishing of textiles, exhibited either absolute decline or a degree of stagnation. On the other hand, there were large increases in certain nontraditional units, especially manufacture of bakery products, manufacture of apparels made of fur and leather, manufacture of costume jewellery, and a phenomenal increase in embroidery, zari and lace work, and manufacture of textile articles other than apparels, the last two belonging to garments and related manufacturing activities (Graph 19.7).

It also showed that unlike in the rural areas, food processing witnessed substantial increases, led by manufacture of bakery (including farinaceous) products and marine processing. Garments and related sectors showed major increases in zari and embroidery-related activities, and some amount 


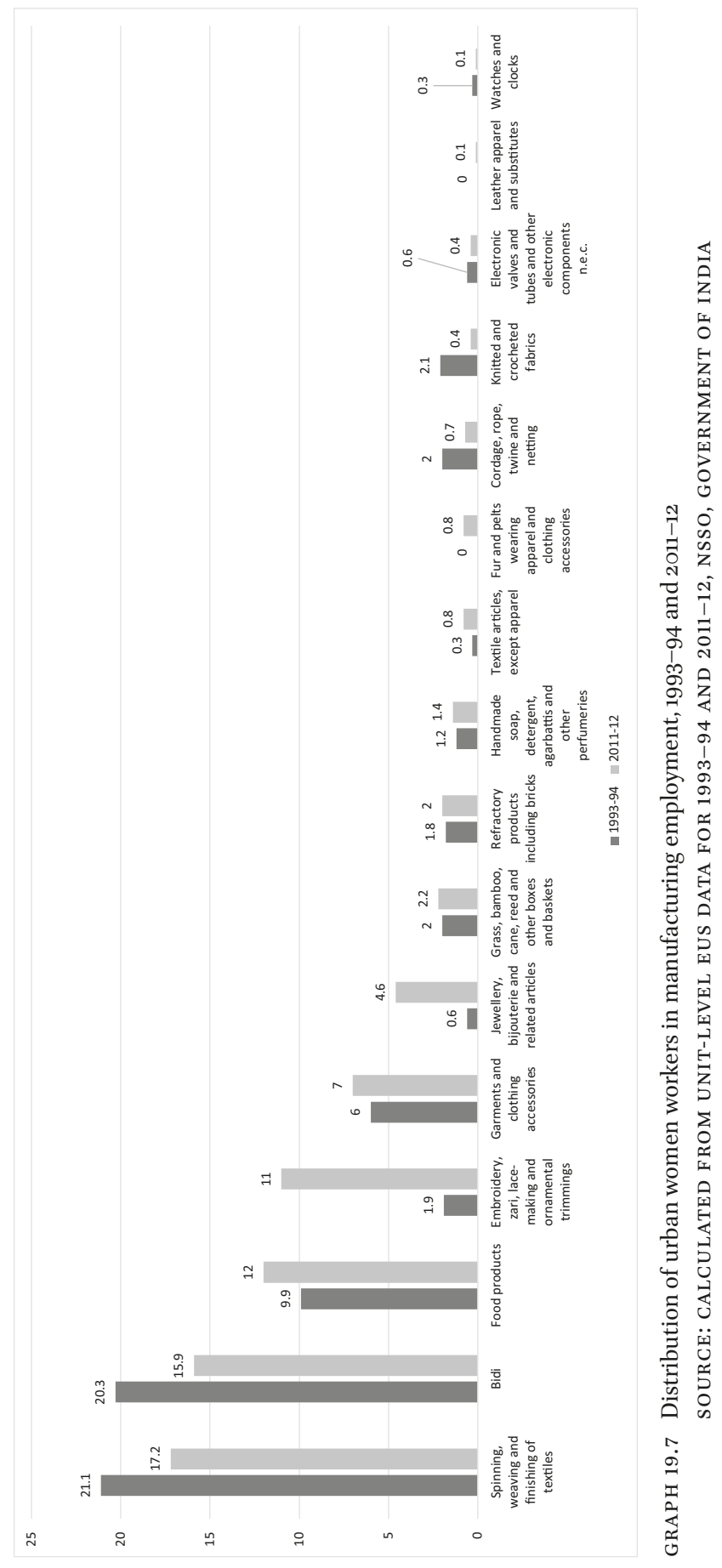


of increase in textile articles other than garments and non-textile garments. However, despite their declining shares, traditional industries, namely bidi manufacture, and spinning and weaving, continued to be the largest employers within manufacturing (Table 19.2). Both Table 19.2 and Graph 19.7 clearly show that among manufacturing activities, the sectors that emerged as important were bidi, food processing, embroidery and zari work, spinning and weaving, manufacture of textile articles and non-textile apparels, and manufacture of costume jewellery.

The trends in Table 19.2 indicate that there were specific changes within manufacturing subsectors, which are not captured when we look at the manufacturing sector as a whole. These suggest that the relatively low increase in manufacturing employment for women workers was due to stagnant or depleted traditional activities. The trends in general also confirm that while some processes moved to factories, newer products emerged using homebased organization of work and engaging women workers within these set-ups. However, it is also clear that the magnitude of such activities was not enough to counter the loss of or slowdown in employment in traditional activities that created an overall dearth of manufacturing work for women, exhibited by the low employment growth rate of the sector.

\section{What Drove Manufacturing Work for Women in India?}

The drivers of such changes in employment patterns within the manufacturing sector can be traced to the emerging patterns of consumption of food and non-food items both globally and locally.

Considering the changes in urban food processing industries, the increases led by processed and packaged food mainly can be traced to globalization. Some studies reported that increased nuclearization of families in a period of rapid globalization induced changes in the domestic consumption and dietary patterns of a section of the population, mainly urban. ${ }^{15}$ Urban consumption baskets have started to include a high proportion of readymade snacks, semicooked and semi-processed condiments and spices, packaged and processed food and beverages, and so on. Such changes in consumption patterns also

15 Prabhu Pingali, "Westernization of Asian Diets and the Transformation of Food Systems: Implications for Research and Policy”, Food Policy, 32:3 (2007), pp. 281-98; S. Mahendra Dev and N.C. Rao, "Food Processing and Contract Farming in Andhra Pradesh: A Small Farmer Perspective”, Economic and Political Weekly, 40:26 (2005), pp. $2705^{-13}$. 
TABLE 19.2 Change in employment in select urban manufacturing sectors, 1993-94 to 2011-12

Sector details
Urban female

absolute

difference
Urban female $\%$ change
255979

75.8

of which:

Processing and preserving of fruit and vegetables (includes jams, pickles, etc.)

Processing and preserving of fish, crustaceans and molluscs and products Bakery products (includes manufacture of farinaceous products like pasta, macaroni, noodles, etc.)

Cocoa, chocolate and sugar confectionery

Processing of edible nuts

Grinding and processing of spices, manufacture of papads, appalams and similar food products

Bidi

Spinning, weaving and finishing of textiles

of which:

Preparation and spinning, weaving, manufacture and finishing of cotton and blended cotton textiles

Preparation and spinning, weaving, manufacture and finishing of other textiles (includes silks, wool, blended)

Knitted and crocheted fabrics

Cordage, rope, twine and netting

Garments and other related sectors

of which:

Embroidery work, zari work and making of laces, fringes and ornamental trimmings All types of textile garments and clothing accessories

Made-up textile articles, except apparel

$\begin{array}{rr}3614 & 68.2 \\ 47957 & 766.3 \\ 138966 & 2357.8 \\ & \\ 24904 & 72.6 \\ 7506 & 22 \\ -3248 & -2.2\end{array}$

99933

14.5

135386

18.9

O

$-12081$

$-2.5$

147467

$64 \cdot 3$

$-53833$

$-75 \cdot 1$

$-34579$

$-50.7$

699118 250.6

483798

$767 \cdot 4$

140862

68.9

30790 
TABLE 19.2 Change in employment in select urban manufacturing sectors (cont.)

Sector details

Urban female

absolute

difference

Wearing apparel made of leather and $55^{26}$

Urban female $\%$ change

Wearing apparel mad
substitutes of leather

Wearing apparel and clothing accessories

made of fur and pelts

Wooden, cane rattan, reed, bamboo,

willow, fibres, leaves and grass articles

Soap and detergents, cleaning and

polishing preparations, perfumes and

toilet preparations and incense sticks

Refractory products and structural clay

38399

62.5

products

Electronic valves and tubes and other

$-2465$

$-11.9$

electronic components n.e.c.

Watches and clocks

Jewellery, bijouterie and related articles

A. Total select manufacturing

B. Total manufacturing employment

40097

58.8

31697

79.8

C. Total non-primary employment

-4830
207969
1464509
$156015^{2}$
9059623

$-54.2$

990.1

61.5

$45 \cdot 9$

86

SOURCE: UNIT-LEVEL EUS DATA FOR 1993-94 AND 2011-12, NSSO, GOVERNMENT OF INDIA.

led to an increase in the demand for packaged and processed food, extensively available at big and middle-level retail outlets spread across urban areas, which in turn was the primary reason for altering the nature of women's work in food processing. It triggered a shift in women's employment from traditional food processing activities to newer forms of processing, especially within packaged food. While such changes were prevalent in urban areas, rural areas that remained relatively less integrated with global factors did not experience similar increases in food processing employment within manufacturing.

It has also been pointed out that many of the activities in food processing are low-productivity activities and occur within an informal set-up, pointing towards an increasing tendency towards home-based work among such activities. The processing of nuts, marine processing, cooperative bakery production 
and so on are some of the examples. A study by Rao and Dasgupta ${ }^{16}$ revealed a high degree of gender segregation of activities within the sector in terms of higher incidence of low-end and non-factory opportunities for women workers.

In the non-food segment, the particular increase of women in garment, electronics and jewellery was driven by increases in global demand patterns. Within garments and related sectors as a whole, the predominance of women was partly a result of increased global integration into global value chains. However, the development of a large domestic market for garments over the last decade also created domestic value chains, which too included a large number of women workers. While readymade garment (RMG) exports increased their share in total exports steadily in the 2000 (except for the period of the global financial crisis in 2008-09), domestic demand for RMG exports also grew by more than 10 per cent from 2004-05. ${ }^{17}$ this increased demand was generated locally. So both global and local demand played a major role in driving employment within the garments sector. However, it is interesting to note that even within garments, if the sector is divided into home workers and factory workers, factory-based employment was dominated by men while women constituted the bulk of home-based workers (discussed in the following section). This held true for women manufacturing workers in both rural and urban areas.

The other important and emerging sector in the last decade which contributed to women's manufacturing employment in urban areas especially was the manufacture of artificial jewellery. The growth of employment in this sector was clearly driven by export-driven production processes, as captured in a study by Sumangala Damodaran. ${ }^{18}$

On the basis of the above analysis of the manufacturing sector over the last two decades, it can be argued that both global and local demand patterns played important roles in driving output growth for the sector, thus impacting women's employment. In addition, the analysis points towards two important findings. It clearly shows a slowdown in manufacturing employment for

16 N.C. Rao and Sukti Dasgupta, "Nature of Employment in Food Processing Sector", Economic and Political Weekly, 44:17 (2009), pp. 109-15.

17 National Council of Applied Economic Research (NCAER), Report on Assessing the Prospects for India's Textile and Clothing Sector, for Ministry of Textiles, Government of India and Confederation of Indian Textile Industry (2009); also available at www.texmin.nic.in, last accessed 2 June 2021.

18 Sumangala Damodaran, "Global Production, Employment Conditions and Decent Work: Evidence from India's Informal Sector”, ILO Working Paper (New Delhi, 2010). 
women, where sectors showing bulk employment of women workers also revealed declining employment growth. It also shows a clear depletion of traditional manufacturing employment in both rural and urban areas, and an emergence of newer manufacturing work for women only in urban areas.

Simultaneously, it reveals that rural manufacturing employment for women was driven mainly by domestic demand patterns, with rural areas remaining more or less excluded from the financialized economic growth process in India (as discussed earlier). However, in urban areas, the driving force of manufacturing employment comprised both domestic and global factors. While employment in traditional activities such as spinning, weaving, bidi manufacture, etc., which had the bulk of women manufacturing workers, catered mostly to domestic demands, garments and apparels were driven by a mix of both, and a few others such as jewellery and some processed food products were solely export-driven. Given this trend in the manufacturing sector, homebased women's work in manufacturing reveals several interesting patterns in recent years.

\section{9}

Dimensions of Home-based Manufacturing Work of Women

Despite the slowdown in manufacturing employment for women in India, it is interesting to note that women's home-based work expanded across several sectors. There were clear extensions of women's home-based work in manufacturing towards food and beverages, apparel and other manufactured products, alongside the existence of home-based work for women within tobacco, wood products, and spinning and weaving. By 2011-12 official statistics on Employment-Unemployment produced by the Government of India, showed that the share of women home-based workers in the manufacturing sector is more than 70 per cent, with a preponderance of home-based work among women in rural areas (Table 19.3). It reconfirms the incidence of home-based work among women being much higher as compared to men.

The distribution of women workers in rural and urban areas by 2011-12 provides a picture of the female clusters of home-based work in manufacturing. While the analysis of rural manufacturing employment among women showed the prevalence of traditional activities, despite a visible decline, 86 per cent of these rural women manufacturing workers were operating within home-based processes of production. The distribution of women workers across sectors showed a predominance of home-based manufacturing work in mostly the traditional sectors, dominated by the rolling of indigenous cigarettes or bidi, followed by garments and textile-related activities under tailoring, embroidery 
TABLE 19.3 Share of home-based manufacturing work in India, 2011-12 ${ }^{\mathrm{a}}$

\begin{tabular}{lclll}
\hline & Rural male & $\begin{array}{l}\text { Urban } \\
\text { male }\end{array}$ & $\begin{array}{l}\text { Rural } \\
\text { female }\end{array}$ & $\begin{array}{l}\text { Urban } \\
\text { female }\end{array}$ \\
\hline $\begin{array}{l}\text { Total home-based } \\
\text { manufacturing work } \\
\text { (HBMw) }\end{array}$ & 4209419 & 2470109 & 6629741 & 4163443 \\
$\begin{array}{l}\text { Total manufacturing } \\
\text { employment }\end{array}$ & 15620226 & 19960206 & 7733771 & 6334622 \\
$\begin{array}{l}\text { Share of HBMw to total } \\
\text { manufacturing }\end{array}$ & 26.9 & 12.4 & $85 \cdot 7$ & $65 \cdot 7$ \\
\hline
\end{tabular}

a Comparability across years in the incidence of home-based work is difficult as the information on the location of workplace for usual status workers is provided by EUS 2011-12; EUS 1993-94 does not contain such information.

SOURCE: CALCULATED FROM UNIT-LEVEL EUS DATA FOR 2011-12, NSSO, GOVERNMENT OF INDIA.

and zari work, and the manufacture of wood and cane products (Graph 19.8). Home-based work within manufacture of jewellery and porcelain and pottery work showed a significantly low presence.

In the urban areas, while the disaggregated distribution of women workers in home-based manufacturing work apparently showed a greater variety of sectors indicating that newer forms of home-based work existed within urban areas, if we aggregate the subsectors in urban areas, it shows that home-based work is dominated by garments and related activities, bidi and food processing. There are also a certain number of workers in manufacture of artificial jewellery, and in leather, fur and pelts (Graph 19.9). It is to be noted that while bidi is not the most important home-based work in urban areas, unlike in rural areas, garments-related work (including tailoring) dominates women's home-based work in the urban context. This should be seen in tandem with the findings of women's work in the urban manufacturing sector, which also highlighted food processing as an important employer of women in manufacturing. "Others", which accounts for a substantial share (2o per cent) of women workers within home-based work, constitutes a range of activities such as manufacture of incense sticks, broomsticks, common pottery, porcelain articles, knitted and crocheted wearing apparels, manufacture of integrated circuits in electrical and electronic equipments, cane products, sports goods, dolls, stuffed toys and 


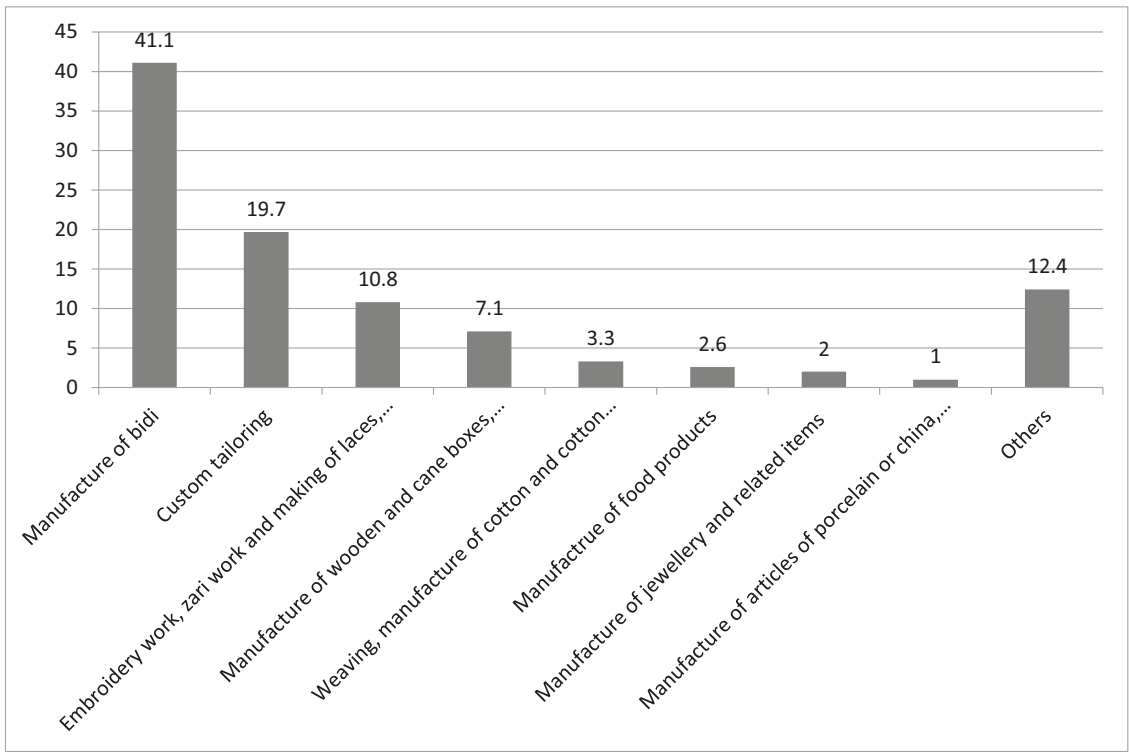

GRAPH 19.8 Distribution of rural women workers in home-based work in manufacturing, 2011-12 SOURCE: CALCULATED FROM UNIT-LEVEL EUS DATA FOR 2011-12, NSSO, GOVERNMENT OF INDIA

animals, and so on. While some of these activities are visible in rural areas, a large number of urban activities spread across different manufacturing sectors among home-based workers are exclusive to urban locations.

Given this distribution of home-based work among women workers in manufacturing in rural and urban areas, it is interesting to look at the incidence of women's home-based work in select sectors. Tables 19.4 and 19.5 clearly show that sectors in which home-based work for women dominates are also the ones that display almost the entire organization of work within the set-up of the home. For example, in rural areas, 97 per cent of all women bidi workers work from home. Similarly, more than go per cent of all women workers in embroidery, zari, tailoring activities and imitation jewellery work under homebased organization of production. These proportions reduce a bit in other sectors such as manufacture of wood, cane products and porcelain products, but remain significantly above 5 o per cent (Table 19.4).

In urban areas similarly, home-based work dominates sectors such as bidi, embroidery, ornamental trimming and tailoring, specific food processing and so on. Sectors like jewellery, food processing, etc., reveal almost 50 per cent of work as home-based. However, manufacture of garments and clothing 


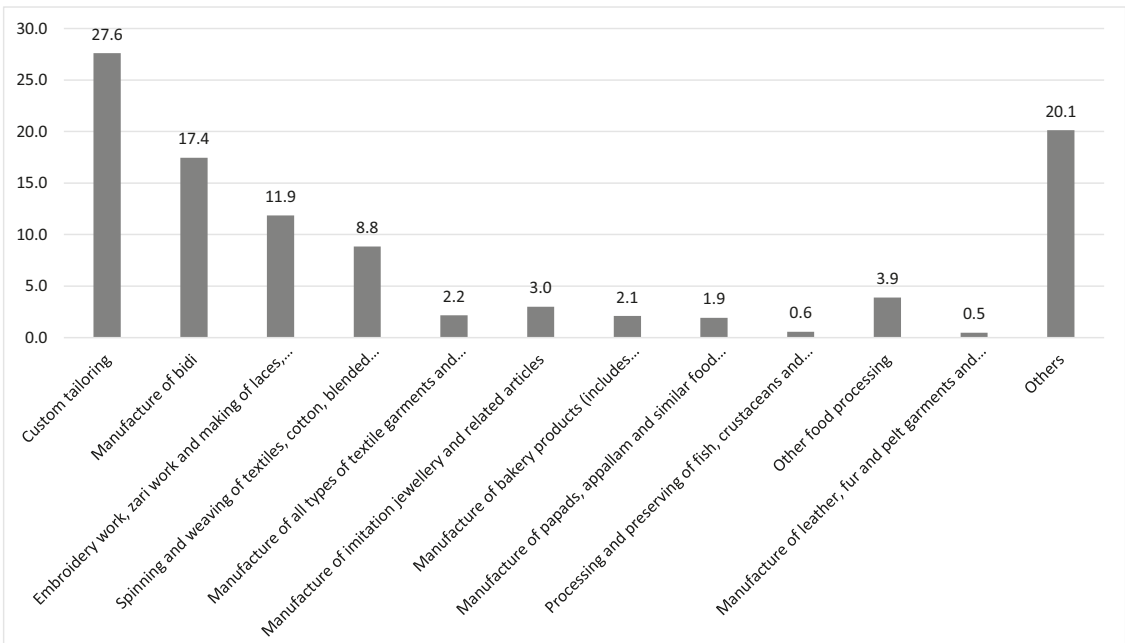

GRAPH 19.9 Distribution of urban women workers in home-based work in manufacturing, 2O11-12 SOURCE: CALCULATED FROM UNIT-LEVEL EUS DATA FOR 2011-12, NSSO, GOVERNMENT OF INDIA

accessories show only 26 per cent incidence of home-based work by women. This indicates a significant presence of factory-based production work for women in this sector. It is also important to note that a few new sectors, such as marine processing and manufacture of leather and pelt items, show 43 per cent incidence of home-based work among women in urban areas (Table 19.5).

\section{Drivers of Home-Based Manufacturing Work of Women in Brief}

The distribution and dimension of home-based women workers across some important sectors provide significant insights. In rural areas, the distribution of home-based work reveals that women were mainly spread across traditional manufacturing sectors such as bidi, wood, cane, rattan products, common pottery and so on, even as these were on the decline. While this definitely highlights the overall crisis of manufacturing employment for women in rural areas, such that women have not been able to find newer employment within manufacturing and have stuck to such low-productivity activities, it should also be noted that these kinds of home-based work are certainly not an outcome of India's drive for economic integration as they existed even prior to the 199os, albeit within a decline in the volume of such manufacturing work post 199os. 
TABLE 19.4 Rural women workers in select home-based manufacturing industries, 2011-12

S. No. Sector details

\section{Total female Home-based HBFWi/ employment female TFi \\ (TFi) employment \\ (HBFWi)}

\begin{tabular}{|c|c|c|c|c|}
\hline 1 & Manufacture of bidi & $28 \circ 5947$ & $27255^{80}$ & 97.1 \\
\hline 2 & Custom tailoring & $147925^{8}$ & 1307621 & 88.4 \\
\hline 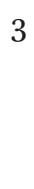 & $\begin{array}{l}\text { Embroidery work, } \\
\text { zari work and making } \\
\text { of laces, fringes and } \\
\text { ornamental trimmings }\end{array}$ & 746114 & 717045 & 96.1 \\
\hline 4 & $\begin{array}{l}\text { Manufacture of wooden } \\
\text { and cane boxes, creates, } \\
\text { drums, barrels and other } \\
\text { containers, baskets } \\
\text { and other wares made } \\
\text { entirely or mainly of } \\
\text { cane, rattan, reed, } \\
\text { bamboo, willow, fibres, } \\
\text { leaves and grass }\end{array}$ & 733486 & 473692 & 64.6 \\
\hline 5 & $\begin{array}{l}\text { Weaving, manufacture } \\
\text { of cotton and cotton } \\
\text { mixture fabrics. }\end{array}$ & 378526 & 219451 & 58.0 \\
\hline 6 & $\begin{array}{l}\text { Manufacture of jewellery } \\
\text { and related items }\end{array}$ & 152962 & 129409 & 84.6 \\
\hline$f$ & $\begin{array}{l}\text { Manufacture of articles } \\
\text { of porcelain or china, } \\
\text { earthenware, imitation } \\
\text { porcelain or common } \\
\text { pottery, including } \\
\text { earthen statues }\end{array}$ & 99292 & 63024 & 63.5 \\
\hline & Total & 7733771 & 6629741 & $85 \cdot 7$ \\
\hline
\end{tabular}

SOURCE: CALCULATED FROM UNIT-LEVEL EUS DATA FOR 2011-12, NSSO, GOVERNMENT OF INDIA. 
TABLE 19.5 Urban women workers in select home-based manufacturing industries, 2011-12

S. Sector details

No.

\section{Total female Home-based HBFWi/ employment female TFi \\ (TFi) employment \\ (HBFWi)}

$\begin{array}{ll}1 & \text { Custom tailoring } \\ 2 & \text { Manufacture of bidi } \\ 3 & \text { Embroidery work, } \\ & \text { zari work and making } \\ \text { of laces, fringes and } \\ \text { ornamental trimmings }\end{array}$

5 Spinning and weaving of textiles, cotton, blended cotton, silk, silk mixtures

8 Manufacture of all types of textile garments and clothing accessories

9 Manufacture of imitation jewellery and related articles

10 Manufacture of bakery products

11 Manufacture of papads, appalams and similar food products

12 Processing and preserving of fish, crustaceans and molluscs and products

13 Manufacture of leather, fur and pelt garments and accessories

$\begin{array}{rrr}1372785 & 1148898 & 83.7 \\ 790045 & 726428 & 91.9 \\ 546840 & 493471 & 90.2\end{array}$

851947

368437

43.2

$\begin{array}{lll}345227 & 89900 & 26.0\end{array}$

127886

84623

66.2

144860

87620

60.5

104326

79886

76.6

54215

23508

$43 \cdot 4$

45065

19667

43.6

Total manufacturing 
Urban areas reveal a slightly different picture. The number of sectors across which women are spread in home-based manufacturing work in urban areas is higher as compared to rural areas. This is in tandem with the relatively greater diversity of activities within urban manufacturing. The analysis also reveals: (i) that there has been some form of employment creation for women in urban areas apart from the declining traditional work; and (ii) that while home-based work is important for women's manufacturing activities, the incidence of factory-based organization of work is not insignificant, unlike in rural areas (Table 19.5). It therefore follows that the prevalence of home-based work is greater in areas with a dominance of traditional work patterns. As regards new employment creation within manufacturing, except for embroidery, zari and other such ornamental and finishing work related to garments, it has been comparatively higher within factories.

Embroidery, zari and ornamental and finishing work related to garments that emerged post-199os had a high incidence of home-based work by women in both rural and urban areas. While in the rural areas the addition of women workers to such work over the last two decades was almost 0.58 million, the percentage increase in such employment in urban areas was higher as compared to rural areas (approximately 770 per cent; Tables 19.1 and 19.2). This clearly implies that in urban areas, over this period, a large number of women entered into such activities, while in rural areas, women were already involved in such work from earlier. The increase in such work in urban areas coincided with the period of globalization and thus can be directly associated with subcontracted/outsourced work by large manufacturers, which may have global linkages. However, the pre-existence of substantial similar work in rural areas prior to globalization indicates that demand for such work existed previously and thus may have been a domestic phenomenon, even if the organization of work may have been different than the current forms of subcontracting.

It therefore follows from the earlier discussion of drivers of manufacturing employment that while domestic demand patterns influenced employment in rural home-based work in manufacturing, urban home-based work was influenced by both local and global factors. The discussion on manufacturing employment clearly noted that the bulk of the increased demand for apparels was not led by export manufacturing but was mainly driven by domestic demand, which in turn drove employment in home-based activities in garments. Other sectors of home-based manufacturing employment, such as processed and packaged food, jewellery, bijouterie, etc., were also influenced by both global and local demand. 
The above discussion and data clearly shows the wide range of activities that women engage in the form of home-based work. These include stitching garments and weaving textiles; embroidery; beading necklace and making bangles; stitching shoe uppers and footballs; producing craft products; processing and preparing food items; rolling incense sticks, bidi, cigarettes and cigars; assembling or packaging electronics, automobile parts and pharmaceutical products mainly within manufacturing sectors such as garments and textiles (especially embellishments and finishing of factory-made garments), handicrafts, leather, toys and sporting goods (e.g., footballs, rackets, nets), jewellery, furniture, carpets and mats, shoes and other footwear, tobacco, incense sticks and flower garlands, processed and cooked food items, electronics, automobiles, pharmaceuticals; manufacturing paper bags and envelopes and so on. Clearly, such forms of work were not driven by global demand and substantial local factors acted as drivers of these activities for women.

It could be argued that home-based work in India was never exclusively driven by globalization as was evident in other Asian countries which experienced a 'feminization' of manufacturing employment. This was mainly due to the strategies of economic integration followed in India, which encouraged a financialized, urban-centric economic growth, rather than growth led by a labour-intensive, export-oriented manufacturing process. Such a strategy culminated in years of "jobless growth" in India starting from the mid-20oos, the repercussions of which are evident in low and declining female work participation rates. This holds true especially in rural areas, which remained excluded from the benefits of the growth process and thus trapped in forms of traditional, low-productive, home-based activities for women within manufacturing, driven mainly by domestic demand patterns.

While home-based work for women thrives on such conditions of work, two further arguments can be made following the above analysis. First, globalization may not be directly driving home-based work for women in manufacturing in India, but it has an indirect impact via altering the domestic consumption patterns of a section of the urban population (discussed in the first section), which in turn drives a substantial part of the home-based manufacturing employment via the typical multiplier effects operating within an economy.

In addition, although manufacturing was not leading the growth process in India and thus remained caught in low-productive activities, the forms of work that evolved under these circumstances were a simple replication 
of the altered forms of global organization of work. In the altered regime of production organization, home-based work for women across the developing countries got a fillip via subcontracting/outsourcing, through the evolution of global production networks and elaborate supply value chains. Several studies have pointed to the worsened conditions of work under such arrangements of work. However, despite the fact that the Indian economy was never an integral part of global export-manufacturing networks, the domestic organization of home-based work also altered following the globalized patterns of organization of work that could accumulate surplus at a relatively faster pace, with greater exploitation and increased vulnerabilities of the workers. This particular observation may be a bit too stretched for the analysis presented in the paper, but can be left open for further explorations. 